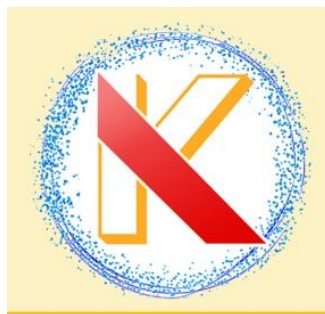

Contents list available at KOVALEN website

KOVALEN: Jurnal Riset Kimia

\title{
Retensi Antosianin dari Ekstrak Daun Bayam Merah (Alternanthera amoena Voss) pada Pengolahan Mie Basah
}

\section{[Retention of Anthocyanin from Red Spinach Leaves Extract (Alternanthera amoena Voss) in Processing Wet Noodles]}

\author{
Betzy Eppang ${ }^{1 *}$, Nurhaeni ${ }^{1}$, Khairuddin $^{1}$, Ahmad Ridhay $^{1}$, Jusman $^{1}$ \\ 1) Jurusan Kimia, Fakultas MIPA, Universitas Tadulako, Jl. Soekarno Hatta Km.9, Kampus Bumi Tadulako Tondo Palu \\ ${ }^{\star}$ Coresponding author: betzynathaliae@gmail.com
}

\begin{abstract}
Research about the retention of red spinach leaves extract (Alternanthera amoena Voss) as a natural coloring and preservative in wet noodles has been done. The study aim is to determine the anthocyanin retention of red spinach leaves extract in the processing of wet noodles and determine the organoleptic quality of wet noodles by adding pigment red spinach leaves extract. The extraction method used the maceration method by ethanol solvent. Anthocyanin levels on an extract that obtained by using a UV-Vis spectrophotometer were $33.34 \%$. Anthocyanin retention of red spinach leaves extract on wet noodle processing at storage times of 0,6 , $12,18,24,30,36,42$, and 48 hours was $100 \%, 75.87 \%, 75.37 \%, 74.95 \%, 74.62 \%, 74.12 \%, 73.28 \%, 71.70 \%$, and $70.61 \%$. Organoleptic quality of wet noodles that was added with extract has "like" to "really like" grade with score detail of the best color of 4.37 at 18 hours storage, whereas the odor, texture, and taste for 0 hours storage have the highest score of $4.63,4.63$, and 4.57 , respectively. The wet noodles with red spinach leaves extract more preferred than the noodles without extracts.
\end{abstract}

Keywords: Retention, anthocyanin, Alternanthera amoena Voss, wet noodles

ABSTRAK. Telah dilakukan penelitian tentang retensi ekstrak daun bayam merah (Alternanthera amoena Voss) sebagai pewarna dan pengawet alami pada mie basah. Tujuan dari penelitian ini mengetahui retensi antosianin dari ekstrak daun bayam merah pada pengolahan mie basah dan mengetahui mutu organoleptik mie basah dengan penambahan pigmen ekstrak daun bayam merah. Metode ekstraksi yang digunakan yaitu maserasi dengan menggunakan pelarut etanol. Hasil penentuan kadar antosianin menggunakan spektrofotometer UV-Vis diperoleh $33,34 \%$. Retensi antosianin ekstrak daun bayam merah pada pengolahan mie basah pada waktu peyimpanan 0, 6, 12, 18, 24, 30, 36, 42, dan 48 jam yaitu 100; 75,87; 75,37; 74,95; 74,62; 74,12; 73,28; 71,70; dan $70,61 \%$. Mutu organoleptik mie basah yang ditambahkan ekstrak berada pada tingkat "suka" hingga "sangat suka" dengan rincian meliputi warna 4,37 untuk penyimpanan 18 jam, aroma 4,63; tekstur 4,63; dan rasa 4,57 untuk penyimpanan $0 \mathrm{jam}$. Mie basah dengan penambahan ekstrak daun bayam merah lebih disukai daripada mie tanpa penambahan ekstrak.

Kata kunci : Retensi, antosianin, Alternanthera amoena Voss, mie basah

Riwayat artikel: Diterima 13 Desember 2019, Disetujui 12 April 2020

Cara sitasi: Eppang, B., Nurhaeni., Khairuddin., Ridhay, A., Jusman. (2020). Retensi Antosianin dari Ekstrak Daun Bayam Merah (Alternanthera amoena Voss) pada Pengolahan Mie Basah. KOVALEN: Jurnal Riset Kimia, 6(1): 53-60.

DOI: https://doi.org/10.22487/kovalen.2020.v6.i1.14795 


\section{LATAR BELAKANG}

Industri dan perkembangan teknologi pangan sangat pesat kemajuannya di Indonesia. Zat-zat adiktif banyak digunakan untuk meningkatkan nilai pangan atau nilai jual suatu produk. Warna merupakan daya tarik terbesar dalam suatu makanan. Hal ini yang membuat berbagai produsen memakai berbagai pewarna dalam produknya (Heyne, 1987). Pewarna sintetik banyak digunakan dalam berbagai industri seperti tekstil, makanan, dan obat-obatan. Penggunaan pewarna sintetik cukup tinggi di Indonesia, tetapi dapat berakibat buruk terhadap kesehatan dan lingkungan.

Penggunaan pewarna sintetik dapat diminimalisir dengan beralih menggunakan pewarna alami yang berasal dari tumbuhan. Zat warna alami dari tumbuhan warnanya lebih menarik dan relatif aman untuk dikonsumsi sehingga dapat meminimalisir timbulnya penyakit yang disebabkan oleh zat warna sintetik. Namun penggunaan zat warna alami belum menjadi pilihan utama di kalangan masyarakat dikarenakan membutuhkan biaya dan waktu cukup banyak dibandingkan dengan zat warna sintetik.

Zat warna atau pigmen dari tumbuhan diekstrak dengan cara menggunakan pelarut yang sesuai kepolarannya dengan zat yang akan diekstrak. Ekstraksi senyawa golongan flavonoid dianjurkan dilakukan pada suasana asam karena asam berfungsi mendenaturasi membran sel tanaman, kemudian melarutkan pigmen antosianin sehingga dapat keluar dari sel, serta mencegah oksidasi flavonoid (Robinson, 1995). Salah satu jenis tumbuhan yang memiliki pigmen dan dapat digunakan pada makanan ialah bayam merah (Althernanthera amoena Voss).
Pigmen yang terdapat dalam bayam merah adalah pigmen antosianin (Pebrianti et al., 2015). Antosianin juga berperan utama sebagai antioksidan yang sangat diperlukan tubuh untuk mencegah terjadinya oksidasi radikal bebas yang menyebabkan berbagai macam penyakit (Lani, 2010). Akhda (2009) melaporkan bahwa kandungan pigmen antosianin pada tanaman dipengaruhi oleh beberapa faktor terutama cahaya matahari (intensitas), suhu udara, dan $\mathrm{pH}$. Antosianin stabil pada $\mathrm{pH}$ 3-5 dan suhu $50^{\circ} \mathrm{C}$, dan dalam penyimpanan $\pm 4^{\circ} \mathrm{C}$ (Adam, 2017).

Antosianin dari bayam merah dilaporkan dapat diekstraksi dengan menggunakan senayawa asam, seperti $\mathrm{HCl}$ dan asam asetat dan menghasilkan warna ungu-kemerahan (Adam, 2017). Antosianin pada daun bayam merah lebih tinggi dibaningkan bagian batang. Daun bayam merah memiliki 6350 ppm, sedang pada batang hanya 2480 ppm (Pebrianti et al., 2015). Pigmen antosianin dari bayam dapat diaplikasi sebagai pewarna pada produk pangan fungsional, seperti mie basah.

Mie basah adalah jenis mie yang mengalami proses perebusan dengan kadar air mie basah matang mencapai 52\%, sehingga daya tahan atau keawetannya cukup singkat. Masa simpan mie basah yang cukup singkat menyebabkan banyak usaha untuk memperpanjang masa simpannya dengan menambahkan pengawet. Pengamatan terhadap mie basah dilakukan terhadap sifat fisik mie, seperti perubahan warna, tekstur, dan kelengketan (Tumbel, 2010).

Pada penelitian sebelumnya, mie basah telah ditambahkan antosianin dari buah naga merah dan menghasilkan mie basah berwarna merah muda dengan tekstur yang elastis dan kenyal dan tidak lengket. Setelah 43 jam mie 
basah menjadi berwarna putih kekuningan, dengan tekstur yang lembek dan berlendir serta berbau asam (Hudaya, 2008). Penggunaan pigmen daun bayam merah diharapkan mampu menghasilkan warna dan tekstru mie basah yang menarik dengan umur simpan yang lama.

\section{METODE PENELITIAN}

\section{Bahan dan Peralatan}

Bahan yang digunakan, yaitu daun bayam merah segar, $\mathrm{HCl}$ p.a, $\mathrm{NaCl}$,etanol $96 \%$, buffer $(\mathrm{KCl}-\mathrm{HCl}) \mathrm{pH} 1$, buffer $\left(\mathrm{C}_{6} \mathrm{H}_{8} \mathrm{O}_{7} \cdot \mathrm{H}_{2} \mathrm{O}-\mathrm{Na}_{3} \mathrm{C}_{6} \mathrm{H}_{5} \mathrm{O}_{7}\right)$ pH 5, akuades, kertas saring, garam dapur, aluminium foil, telur, tepung terigu, tepung ubi kayu, minyak sawit, kertas label, aluminium foil, dan tisu.

Alat yang digunakan, yaitu radas penguap putar, labu takar, gelas kimia, tabung reaksi, corong buchner, pompa vakum, spektrofotometer UV-Vis PerkinElmer L850, $\mathrm{pH}$ meter, sendok zat, rak tabung, corong kaca, neraca analitik Ohaus Corp. Pine Brook, baskom, ember, penggiling mie, kompor, dan pisau.

\section{Prosedur Penelitian}

\section{Ekstraksi zat warna dari daun bayam merah}

Zat warna diekstraksi dengan metode maserasi selama 2 kali 24 jam. $500 \mathrm{~g}$ daun bayam merah ditambahkan $1000 \mathrm{~mL}$ etanol 96\% dengan rasio perbandingan antara sampel dan pelarut sebesar $1: 2$ (b/v). Hasil ekstraksi disaring menggunakan corong buchner dengan bantuan pompa vakum untuk memisahkan ekstrak dari residu. Ekstrak yang didapatkan kemudian dipisahkan dari pelarutnya dengan menggunakan rotary vakum evaporator sehingga diperoleh ekstrak pekat (Adam, 2017). Panjang gelombang maksimum ekstrak pigmen daun bayam merah ditentukan menggunakan spektrofotometer UV-Vis.

\section{Aplikasi ekstrak daun bayam merah pada pembuatan mie basah}

Metode yang digunakan adalah modifikasi dari prosedur kerja Mappiratu (2012) dan Noviyandari et al. (2019). Tepung mie dan tepung tapioka dengan konsentrasi 3 : 1 dicampurkan lalu ditambahkan bahan pembantu lain, seperti garam dapur sebanyak setengah sendok teh, 2 butir putih telur, 1 sendok teh minyak. Dilakukan pengadukan dengan mixer selama 5 menit agar adonan tercampur secara merata. Setelah itu ditambahkan $5 \mathrm{~mL}$ ekstrak daun bayam merah kemudian dilakukan pengadukan hingga adonan homogen selama 5 menit menggunakan mixer. Setelah adonan yang terbentuk sudah homogen maka adonan perlu didiamkan sebentar selama 5 menit yang berfungsi untuk membantu ekstrak untuk bereaksi membentuk gluten. Tahap selanjutnya adalah pembentukan lembaran. Lembaran tersebut didiamkan selama 15 menit yang bertujuan untuk menyempurnakan pembentukan gluten. Pembentukan untaian mie dilakukan dengan membentuk mie menjadi untaian benang-benang mie yang memiliki tebal 1-3 mm dengan menggunakan alat penggiling mie. Proses selanjutnya mie langsung direbus selama 2 menit dan dikukus selama 13 menit. Setelah itu didinginkan dalam air es selama 1 menit untuk menghilangkan sisa uap panas saat proses perebusan dan pengukusan. Tahap terakhir dalam pembuatan mie basah matang adalah pemberian minyak sawit, dengan tujuan agar untaian mie tidak lengket satu sama lain, memberikan cita rasa, serta meningkatkan 
warna dan penampakan mie agar tampak lebih mengkilap.

\section{Penentuan kadar total antosianin}

Kadar total antosianin dihitung dengan menggunakan Persamaan 1 (Adam, 2017):

$$
\mathrm{C}_{\text {antosianin }}(\mathrm{mg} / \mathrm{L})=\frac{\mathrm{A} \times \mathrm{MW} \times \mathrm{DF} \times 1000}{\in \times \mathrm{I}}
$$

Keterangan :

$\mathrm{C}_{\text {antosanin }}=$ Konsentrasi monomer antosianin

$$
\begin{aligned}
& \text { A } \quad=\left(A_{400}-A_{600}\right) \mathrm{pH} \mathrm{1,0}-\left(\mathrm{A}_{400}-\mathrm{A}_{600}\right) \mathrm{pH} \mathrm{5,0} \\
& \in=\quad=\text { Adsorbsivitas molar sianidin 3-glukosida } \\
& 26900 \text { L/mol.cm } \\
& \mathrm{L}=\quad=\text { Lebar kuvet }(1 \mathrm{~cm}) \\
& \text { MW = BM sianidin-3-glukosida }=449,2 \mathrm{gr} / \mathrm{mol} \\
& \text { DF } \quad=\text { Faktor Pengenceran }
\end{aligned}
$$

\section{Uji organoleptik ekstrak daun bayam merah pada mie basah}

Mie basah yang dihasilkan diuji secara organoleptik (uji hedonik) oleh 30 panelis. Panelis menggunakan 5 skala untuk mengetahui tingkat kesukaan terhadap mie yang dihasilkan. Atribut mutu yang dinilai adalah warna, bau, tekstur, dan rasa dengan masing-masing menggunakan 5 skala untuk skala 1 = sangat tidak suka, 2 = tidak suka, 3 = agak suka, 4 = suka dan 5 = sangat suka. Mie terbaik ditemukan berdasarkan uji pembobotan. Uji pembobotan dilakukan secara organoleptik menggunakan 30 panelis. Panelis memberikan bobot terhadap atribut mutu rasa dan tekstur. Mie yang mempunyai bobot paling tinggi dinyatakan sebagai produk terbaik (Bambang et al., 1988).

\section{Penentuan retensi warna}

Retensi warna antosianin yang tidak terkopigmentasi dan yang terkopigmentasi selama penyimpanan $(0,6,12,18,24,30,36$, 42 , dan 48 jam) diamati melalui pengukuran absorban ekstrak antosianin daun bayam merah pada larutan buffer pH 5 (Robinson, 1995). Retensi warna selama penyimpanan dihitung dengan menggunakan Persamaan 2.

$$
\text { Retensi warna }(\%)=\mathrm{C}_{0}-\mathrm{C}_{\mathrm{t}}
$$

Keterangan:

$$
\begin{aligned}
& \mathrm{C}_{0}=\text { konsentrasi antosianin awal (\%) } \\
& \mathrm{C}_{\mathrm{t}}=\text { konsentrasi antosianin tersisa (\%) }
\end{aligned}
$$

\section{HASIL DAN PEMBAHASAN}

\section{Ekstrak Bayam Merah}

Pelarut yang digunakan pada proses ekstraksi adalah etanol $96 \%$, karena merupakan pelarut organik yang bersifat polar. Menurut (Wulaningrum et al., 2013) Senyawa golongan flavonoid termasuk senyawa polar dan dapat diekstraksi dengan pelarut yang bersifat polar pula (like dissolve like). Sementara itu berdasarkan sifat fisik sampel antosianin terlihat bahwa antosianin yang dihasilkan dengan menggunakan pelarut etanol menghasilkan warna yang lebih cerah dan menarik dibandingkan dengan menggunakan pelarut aquadest yang cederung menghasilkan warna yang tidak begitu cerah. Hal ini disebabkan oleh karena pelarut etanol sangat baik digunakan sebagai pelarut antosianin.

Analisis spektrum UV-Vis ekstrak antosianin dari daun bayam merah menghasilkan panjang gelombang maksimum 530 nm (Gambar 1). Hasil ini berada pada serapan senyawa antosianin yang terletak pada panjang gelombang 400-600 nm (Harborne, 1987). Menurut penelitian Adam (2017), nilai $\lambda$ maksimum antosiani pada daerah Vis, yaitu $536 \mathrm{~nm}$ yang merupakan senyawa antosianin berjenis sianidin. 


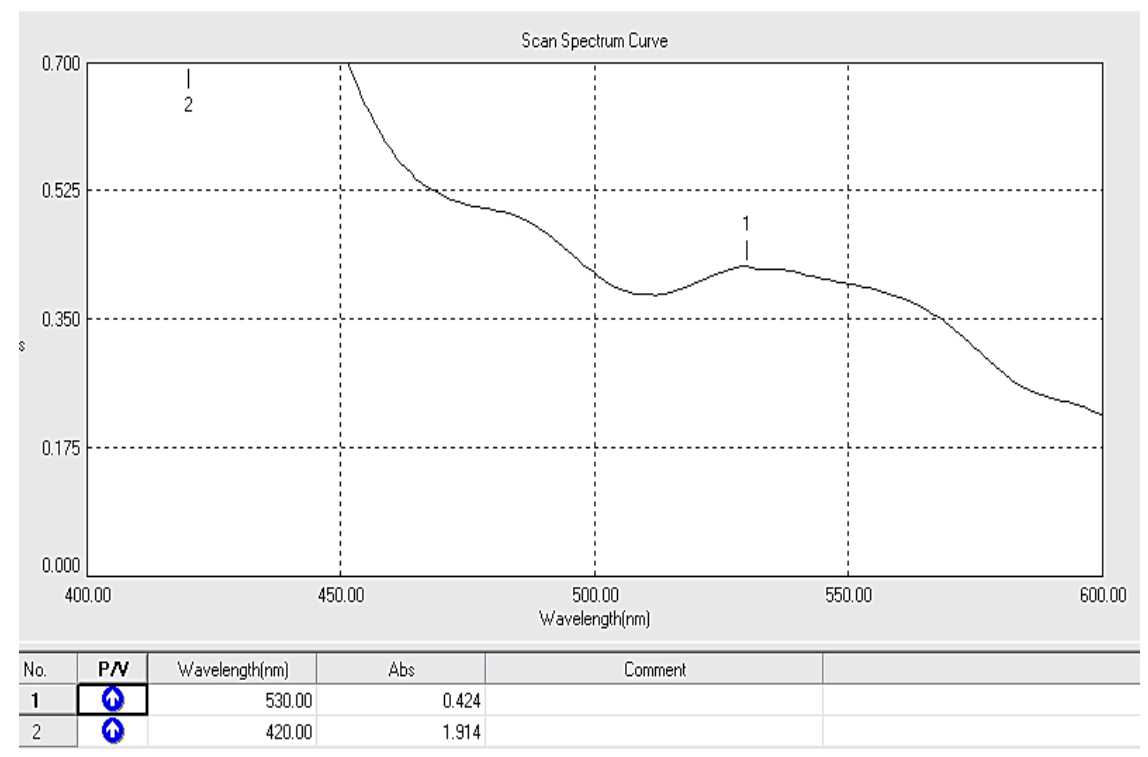

Gambar 1. Panjang gelombang maksimum ekstrak daun bayam merah

\section{Retensi Antosianin dari Ekstrak Daun Bayam Merah}

Ekstrak daun bayam merah diaplikasikan pada mie basah. Hal ini karena kandungan antosianin pada ekstrak daun bayam merah cukup tinggi, sehingga dapat dijadikan sebagai pengawet alami pada mie basah (Durst \& Wrolstad, 2005). Mie basah umumnya berwarna putih kekuningan, warna ini disebabkan karena kandungan flavonoid yang terdapat pada tepung terigu (Sihombing, 2007).

Umur simpan ekstrak daun bayam merah pada mie basah lebih dari 48 jam, karena retensi antosianin masih 70,61\% (Gambar 2). Pangan fungsional dikatakan masih baik untuk dikonsumsi jika kadar bahan aktif didalamnya masih diatas 30\% (Mappiratu, 2012).

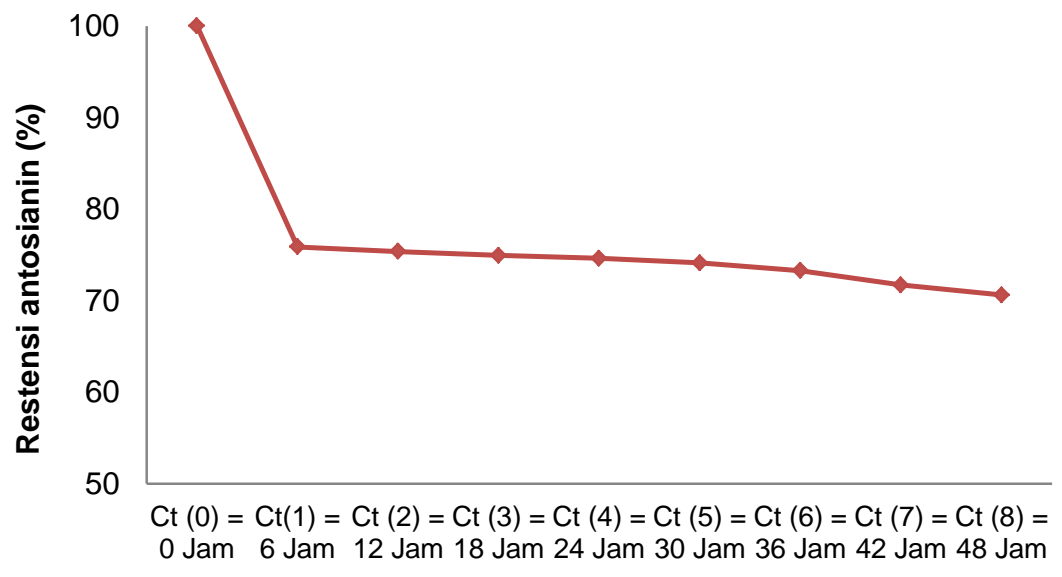

\section{Waktu Penyimpanan}

Gambar 2. Retensi antosianin dari ekstrak daun bayam merah pada variasi waktu penyimpanan

Pada penelitian ini menunjukan bahwa retensi antosianin dari ekstrak daun bayam merah pada rentang waktu $0,12,18,24,30$,
36, 42, dan 48 jam, berturut-turut $100 \%$; $75,87 \% ; 75,37 \% ; 74,95 \% ; 74,62 \% ; 74,12 \%$; $73,28 \%$; $71,70 \%$; dan $70,61 \%$ pada $\mathrm{pH} 5$ atau 
mengalami penurunan seiring dengan bertambahnya waktu simpan (Gambar 2). Retensi terendah terjadi pada waktu 42 dan 48 jam, yaitu 71,70 dan 70,61 \%. Masa penyimpanan 42 dan 48 jam mengalami degradasi yang cukup tinggi dibandingkan dengan masa penyimpanan 6 dan 12 jam.

Faktor yang mempengaruhi retensi antosianin adalah struktur antosianin dan komponen-komponen lain yang terdapat pada bahan pangan tersebut. Antosianin dapat membentuk kompleks dengan komponen polifenolik lainnya. Komponen flavonol dan flavon yang biasanya selalu berkonjugasi dengan antosianin juga memiliki kontribusi dalam menjaga stabilitas antosianin (GómezPlaza et al., 2006). Peningkatan pH akan membuat warna antosianin memudar karena kation flavilium yang berwarna merah mengalami hidrasi menjadi karbinol yang tidak berwarna sehingga penggunaan $\mathrm{pH}$ rendah lebih baik bagi kestabilan antosianin (Hidayah et al., 2014).

Selain analisis kadar antosianin, juga dilakukan pengamatan fisik mie basah yang dibandingkan dnegan mie tanpa ekstrak (kontrol). Penambahan ekstrak daun bayam merah pada mie basah lebih baik dibandingkan dengan tanpa ekstrak, karena ekstrak segar pada mie basah tidak terjadi pertumbuhan jamur dan bakteri yang dapat mempercepat masa simpan mie basah sehingga ketahanan mie basah lebih lama. Mie basah tanpa ekstrak pada penyimpanan setelah 48 jam menjadi berlendir dan berbau asam yang diakibatkan oleh bakteri, selain itu pada permukaan mie terdapat jamur. Sebagai solusi penyimpanan, mie basah diperkaya antosianin lebih baik disimpan di dalam ruang pendingin dibandingkan dengan disimpan di ruang terbuka.

\section{Mutu Organoleptik Mie Basah dengan Ekstrak Daun Bayam Merah.}

Hasil uji organoleptik terhadap warna, tekstur, bau, dan rasa menunjukkan bahwa sampel dengan perlakuan penambahan ekstrak pada mie basah memiliki skor tertinggi dan berada rentang penerimaan "suka" hingga "sangat suka" dari 30 panelis pada waktu pemyimpanan 0 jam, 6 jam, 12 jam, 18 jam, 24 jam, 30 jam, 36 jam, 42 jam dan 48 jam. Ratarata tingkat penilaian kesukaan terhadap mie basah dengan penambahan ekstrak daun bayam merah yaitu warna 4,37; aroma 4,63; tekstur 4,63; dan rasa 4,57, sedangkan tanpa penambahan ekstrak memiliki skor warna 4,13; aroma 3,77; tekstur 3,70; dan rasa 3,83. Hasil ini menunjukan bahwa penambahan ekstrak daun bayam merah pada pengolahan lebih disukai daripada tanpa penambahan ekstrak (Gambar 3).

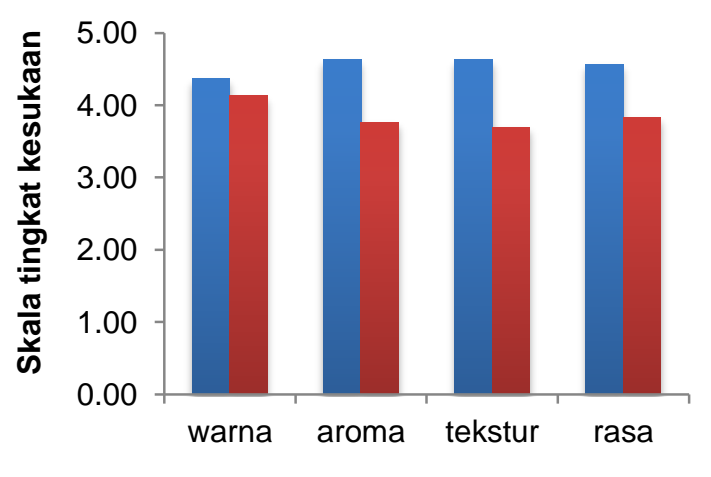

Flavor

- mie dengan ekstrak - mie tanpa ekstrak

Gambar 3. Perbandingan tingkat kesukaan mie basah dengan dan tanpa penambahan ekstrak antosianin

Kandungan antosianin pada ekstrak mampu dijadikan pewarna alami pada makanan, sehingga membuat makanan menjadi tahan lama, dan tentunya memiliki cita 
rasa yang khas, dari segi warna yang menarik, bau yang khas, tekstur sangat lembut dan tidak melengket, dan rasa yang tentunya nikmat yang bercirikhas bayam, dibandingkan yang tanpa menggunakan ekstrak dari segi warna yang pudar, tekstur lengket bau yang berubah, semakin lama terasa menyengat, dan rasanya seperti mie pada umumnya. Menurut Siregar (2008), semakin tinggi nilai organoleptik suatu bahan makanan, maka semakin berpeluang pula produk tersebut untuk diterima di masyarakat luas sebagai calon konsumen.

\section{KESIMPULAN}

Retensi antosianin ekstrak daun bayam merah dalam mie basah pada rentang waktu $0,6,12,18,24,30,36,42$, dan 48 jam, yaitu 100; 75,87; 75,37; 74,95; 74,62; 74,12; 73,28; 71,70 ; dan $70,61 \%$. Mutu organoleptik mie intsan yang ditambahkan ekstrak berada pada tingkat sangat suka dengan rincian meliputi warna 4,37 untuk penyimpanan 18 jam, aroma 4,63; tekstur 4,63; dan rasa 4,57 untuk penyimpanan 0 jam. Disimpulkan pula bahwa mie instan dengan penambahan ekstrak bayam merah lebih disukai daripada mie tanpa penambahan ekstrak.

\section{DAFTAR PUSTAKA}

Adam, D. H. (2017). Penentuan Antosianin dari Daun Bayam Merah (Alternanthera amoena Voss.) serta Alikasinya Sebagai Pewarna Minuman. Jurnal Pembelajaran Dan Biologi Nukleus. 3(1): 10-16. https://doi.org/10.36987/jpbn.v3i1.1197

Akhda, D. (2009). Pengaruh dosis dan Waktu Aplikasi Kompos Azolla sp. Terhadap Pertumbuhan Tanaman Bayam Merah (Alternanthera amoena voss). [Skripsi]. Fakultas Sains dan Teknologi UIN Malang, Malang.
Bambang, Kartika, Pudji, H., \& Wahyu, S. (1988). Pedoman Uji Indrawi Bahan Pangan. UGM, Yogyakarta.

Durst, R., \& Wrolstad, R. (2005). Characterization and Measurement of Anthocyanins by UV-visible Spectroscopy. In R. E. Wrolstad (Ed.), Handbook of Analytical Food Chemistry. John Wiley \& Sons, New York.

Gómez-Plaza, E., Miñano, A., \& López-Roca, J. M. (2006). Comparison of chromatic Properties, Stability and Antioxidant Capacity of Anthocyanin-Based Aqueous Extracts from Grape Pomace Obtained from Different Vinification Methods. Food Chemistry, 97(1): 87-94. https://doi.org/10.1016/j.foodchem.2005.0 3.025

Harborne. (1987). Metode Fitokimia: Penuntun Cara Modern Menganalisis Tumbuhan. ITB, Bandung.

Heyne, K. (1987). Tumbuhan Berguna Indonesia Jilid III. Yayasan Sarana Wana Jaya, Jakarta.

Hidayah, T., Pratjojo, W., \& Widiarti, N. (2014). Uji Stabilitas Pigmen dan Antioksidan Ekstrak Zat Warna Alami Kulit Buah Naga. Indonesian Journal of Chemical Science, 3(2).

Hudaya, R. (2008). Pengaruh Penambahan Tepung Rumput Laut (Kappaphycus alvarezii) untuk Peningkatan Kadar Yodium dan Serat Pangan pada Tahu Sumedang. [Skripsi]. FPIK Institut Pertanian Bogor, Bogor.

Lani, L. (2010). Cerdas Memilih Sayuran. PT Agro Media Pustaka, Jakarta.

Mappiratu. (2012). Teknologi Pangan. Universitas Tadulako, Palu.

Noviyandari, D., Hardi, J., \& Mappiratu, M. (2019). Aplikasi Ekstrak Likopen dari Buah Tomat Apel (Lycopersicum pyriforme) Tersalut Maltodekstrin pada Pengolahan Mie Instan Fungsional. KOVALEN: Jurnal Riset Kimia, 5(3): 322329.

https://doi.org/10.22487/kovalen.2019.v5.i 3.14799 
Pebrianti, C., Ainurrasyid, R., \& Purnamaningsih, S. (2015). Test Anthocyanin Content and Yield of Six Varieties Red Spinach. Jurnal Produksi Tanaman, 3(1): 27-33.

Robinson, T. (1995). Kandungan Organik Tumbuhan Tinggi. Edisi ke-6. Penerjemah: Kosasih Padmawinata. ITB, Bandung.

Sihombing, P. (2007). Aplikasi Ekstrak Kunyit (Curcuma domestica) sebagai Bahan Pengawet Mie Basah. [Skripsi]. FTP Institut Pertanian Bogor, Bogor.

Siregar, S. (2008). Penggemukan Sapi. Penebar Swadaya, Jakarta.

Tumbel, M. (2010). Analisis Kandungan Boraks Dalam Mie Basah yang Beredar di Kota Makassar. Jurnal Chemica, 11(1): 57-64.

Wulaningrum, R. A., Sunarto, W., \& Alauhdin, M. (2013). Pengaruh Asam Organik dalam Ekstraksi Zat Warna Kulit Buah Manggis (Garcinia mangostana). Indonesian Journal of Chemical Science, 2(2). 